\title{
Biocompatibility of crystalline opal nanoparticles
}

\author{
Marlen Hernández-Ortiz ${ }^{1+}$, Laura S Acosta-Torres ${ }^{3+}{ }^{+}$Genoveva Hernández-Padrón ${ }^{4+}$, Alicia I Mendieta ${ }^{6+}$, \\ Rodolfo Bernal ${ }^{7 \dagger}$, Catalina Cruz-Vázquez ${ }^{2 \dagger}$ and Victor M Castaño ${ }^{5,8^{*}}$
}

* Correspondence: meneses@unam.
mx
${ }^{\dagger}$ Equal contributors
${ }^{5}$ Departamento de Ingeniería
Molecular de Materiales, Centro de
Física Aplicada y Tecnología
Avanzada, Campus Juriquilla,
Querétaro 76230, México
${ }^{8}$ Centro de Física Aplicada y
Tecnología Avanzada, Universidad
Nacional Autónoma de México,
Campus Juriquilla, Querétaro 76230,
México
Full list of author information is
available at the end of the article

\begin{abstract}
Background: Silica nanoparticles are being developed as a host of biomedical and biotechnological applications. For this reason, there are more studies about biocompatibility of silica with amorphous and crystalline structure. Except hydrated silica (opal), despite is presents directly and indirectly in humans. Two sizes of crystalline opal nanoparticles were investigated in this work under criteria of toxicology.

Methods: In particular, cytotoxic and genotoxic effects caused by opal nanoparticles ( 80 and $120 \mathrm{~nm}$ ) were evaluated in cultured mouse cells via a set of bioassays, methylthiazolyldiphenyl-tetrazolium-bromide (MTT) and 5-bromo-2/-deoxyuridine (BrdU).

Results: 3T3-NIH cells were incubated for 24 and $72 \mathrm{~h}$ in contact with nanocrystalline opal particles, not presented significant statistically difference in the results of cytotoxicity. Genotoxicity tests of crystalline opal nanoparticles were performed by the BrdU assay on the same cultured cells for $24 \mathrm{~h}$ incubation. The reduction of BrdU-incorporated cells indicates that nanocrystalline opal exposure did not caused unrepairable damage DNA.
\end{abstract}

Conclusions: There is no relationship between that particles size and MTT reduction, as well as BrdU incorporation, such that the opal particles did not induce cytotoxic effect and genotoxicity in cultured mouse cells.

Keywords: Cytotoxicity, Genototoxicity, Synthetic opal, BrdU and MTT assay

\section{Background}

Technology is now available to produce nanoparticles materials, with a wide range of size distributions, shapes and modified surface functions. Particularly, silicon nanoparticles, are of interest as a biomarker because they are potentially bioinert and do not require a thick protective shell [1-4]. In addition, silica nanoparticles are being developed as a host of biomedical and biotechnological applications such as cancer therapy, DNA transfection, drug delivery and enzyme immobilization [5-7].

The extensive use of nanomaterials has promoted the study of nanotoxicology in parallel to the development of applications. This is due to the fact that the surfaces of biomaterials (e.g., implants and medical devices) are immediately covered by biomolecules (e.g., proteins, natural organic materials, detergents, and enzymes) as they come into contact with a biological medium. Nanoparticles coated with proteins have a conformation that may be disrupted or induced to aggregate, which, in turn, can trigger unexpected cellular responses. The key role of protein-nanoparticle interactions in

(c) 2012 Hernandez et al.; licensee BioMed Central Ltd. This is an Open Access article distributed under the terms of the Creative Commons Attribution License (http://creativecommons.org/licenses/by/2.0), which permits unrestricted use, distribution, and reproduction in any medium, provided the original work is properly cited. 
nanomedicine and nanotoxicity has begun to emerge recently via the identification of the nanoparticle and protein corona. This dynamic layer of proteins and/or other biomolecules adsorbed to the nanoparticle surface determines how a nanoparticle interacts with living systems and thereby modifies the cellular responses [8-11].

The affinity and amount of proteins adsorbed on the surfaces of nanoparticle are highly dependent on the nanomaterial composition, size and surface chemistry [10]. For example, the nano-sized silica can generate adverse effects, like liver injury and inflammation; and the exposure of amorphous spherical silicon dioxide nanoparticles of different sizes induces decreases in viability of human endothelial cells, an expression of its cytotoxicity which was apparently dependent of the particle size. Besides, each organ has different reactions; some studies indicate that nano-silica can cause cytotoxicity and primary damage in DNA but not mutagenicity in cultured mammalian cells $[2,6,12-16]$.

Specifically, a polymorphous of the silica, called opal, has not been studied regarding its biocompatibility. Opal is a natural hydrous silica with either amorphous (opal-A) or ordered cristobalite structures (opal-C) and a spherical shape over a wide range of diameters from several tens of nanometers to various micrometers [17-19]. Humans are exposed directly and indirectly to opals. For example, some animals and plants contain opal as a cross-linking agent in connective tissues $[20,21]$ and the infiltration of biomolecules in photonic crystals to get improved luminescence spectra of DNA infiltrated opal due to the possible formation of new photon-electron bound states [22]. The last study was made in vitro and does not consider toxicity tests. For this reason, the aim of the present work is to investigate in vitro whether nanocrystalline opal synthetized by sedimentation method could induce cytotoxic and genotoxic effects in 3T3-NIH mouse epithelial cells, using MTT and BrdU assays, respectively.

\section{Cytotoxicity of magnetic nanoparticles}

Advancements in nanotechnology over the last 20 years have led to the development of novel magnetic nanoparticles. The general theory of nuclear relaxation in the presence of paramagnetic substances is based on a monocrystalline or polycrystalline iron oxide core with a diameter of 5-30 nm embedded within a polymer coating [23]. Superparamagnetic iron oxide nanoparticles (SPIONs) are used in a large variety of biomedical applications, such as cell labeling, hyperthermia, controlled drug delivery, in vivo cell tracking, hyperthermia, treatment of cancer, as magnetic resonance imaging (MRI) contrast agents, including [24-27]. Among all types of nanoparticles, SPIONs are the most promising candidates for use as contrast agents not only for their suitable magnetic saturation and superparamagnetic properties, but also due to their colloidal stability and biocompatibility $[23,24,26,28,29]$.

In summary, cytotoxity of magnetic nanoparticles is strongly dependent of their chemistries and physics characteristic, cell lines, cell cycle and examined technique. The manner in which SPIONs are chemically modified will indeed impact cytotoxicity outcomes in vitro and also the toxicokinetics and dynamics in vivo [23]. Cytotoxicity of the bare and coated SPIONs has been assessed via various methods such as the cell-life cycle assay, MTT assay, comet assay, TUNEL assay (i.e., for apoptosis detection), and several in vivo models [28]. 
The relation with this paper is based in that mesoporous silica is the magnetic carrier in whose pores is adsorbed the drug [24]. Specifically, silica has also received tremendous attention given its long industrial history as an occupational carcinogen. Also nanoscale silica can disrupt nuclear integrity by forming intranuclear protein aggregates that can lead to inhibition of replication, transcription and cell proliferation, as reported by Chen et al. [26].

\section{Methods}

\section{Production and characterization of opal nanoparticles}

Synthetic opals were produced by Stöber technique [30]. Nanodispersive silica spheres near 80 and $120 \mathrm{~nm}$ in diameter were synthesized through the sol-gel process of tetraethyl orthorsilicate (TEOS; $\left.\mathrm{Si}\left(\mathrm{OC}_{2} \mathrm{H}_{5}\right)_{4}\right)$ in a water-ethanol solution with presence of ammonium hydroxide as a catalyst, each particle size corresponds at a batch called $\mathrm{O} 1$ and $\mathrm{O} 2$, respectively. The colloid solutions were dried at $60^{\circ} \mathrm{C}$. Finally, samples were sintered to $1150^{\circ} \mathrm{C}$ for 2 days with extreme sluggishness.

The structure and the morphology of samples were characterized by X-Ray Diffraction (XRD), using a Rigaku diffractometer, model Miniflex, with $\mathrm{Cu} K \alpha$ radiation, and Scanning Electron Microscopy (SEM) analysis, obtained with a JEOL JSM-6060LV microscope using gold as coater.

The purity of opal nanoparticles was proved with infrared spectroscopy (FTIR), using a Perkin-Elmer Spectrum GX by the KBr pellet method; and a chemical analysis by energy-dispersive spectroscopy (EDS) was developed in a JEOL JSM-5410LV Scanning Microscope.

\section{Preparation of opal nanoparticles}

Opals were added into $15 \mathrm{~mL}$ acid mixture of $\mathrm{H}_{2} \mathrm{SO}_{5}: \mathrm{HNO}_{3}$ (3:1) in an ultrasonic bath for $24 \mathrm{~h}$, then in $0.1 \mathrm{M} \mathrm{NaOH}$ aqueous solution at $90^{\circ} \mathrm{C}$ for $2 \mathrm{~h}$, finally in $0.1 \mathrm{M} \mathrm{HCl}$ aqueous solution at $90^{\circ} \mathrm{C}$ for $2 \mathrm{~h}$. Thereafter, the treated opals were washed with distilled water and then centrifuged and dried. After drying, the particles were dissolved in distilled water and the solution was sonicated for $20 \mathrm{~min}$ before the cell evaluations.

\section{Cell line and culture}

The 3T3-NIH mouse fibroblast were cultured in DMEM (Dulbecco's Modified-Eagle medium) supplemented with FBS (Fetal Bovine Serum, 10\%) and penicillinstreptomycin (1\%). The mouse fibroblasts were seeded in 24 -well plates $\left(1 \times 10^{4}\right.$ cells $)$ during $24 \mathrm{~h}$, and then the medium was renewed and the experimental opals samples were put in contact with cells.

\section{Cytotoxicity assay}

The cytotoxicity of particles was determined using the MTT assay [31]. Briefly, opal particles were set in contact with cells and incubated in a volume of $500 \mu \mathrm{L}$ into each well of a 24-well plate during 24 and $72 \mathrm{~h}$. After each period of time, the MTT reagent was added to each well at a final concentration of $0.5 \mathrm{mg} / \mathrm{mL}$ and plates were incubated at $37^{\circ} \mathrm{C}$ for $40 \mathrm{~min}$. Next, a solubilizing solution was added to each well and mixed thoroughly during $5 \mathrm{~min}$. The optical density (OD) was read on a spectrophotometric 
ELISA plate reader at a wavelength of $570 \mathrm{~nm}$. Cells not in contact with opals nanoparticles were used as control group. The results of the experiments were expressed as percentage of cell viability.

\section{Genotoxicity assay}

The quantitative determination of DNA synthesis in cells was measured using a modified BrdU test. After the cell incubation for $24 \mathrm{~h}$, the BrdU labeling reagent was added and the cells were incubated again for further $4 \mathrm{~h}$. During this period, the thymidine analogue BrdU is incorporated instead of thymidine into the DNA of proliferating cells. After removing the culture medium, the cells were fixed and the DNA was denatured in one step by adding FixDenat. The quantity of BrdU incorporation was detected by the monoclonal antibody from mouse hybrid cells conjugated with peroxidase (antiBrdU-POD) which binds to the BrdU in newly synthesized cellular DNA. These immune complexes were detected by the subsequent substrate reaction and after addition of the stop solution $\left(1 \mathrm{~mol} / \mathrm{L} \mathrm{H}_{2} \mathrm{SO}_{4}\right)$ the colorimetric measurement of $\mathrm{BrdU}$ was started with the respective wavelength $450 \mathrm{~nm}$ in an ELISA microreader. The color intensity and thereby the absorbance directly correlated to the amount of DNA synthesis and hereby to the number of proliferating cells. The percentage of BrdU incorporation was determined by the analysis of cells treated with test substances, compared to controls.

\section{Statistical analysis}

The MTT and BrdU experiments were run using $n=3$ on each group. Statistical analysis was carried out using Student's $t$-test and Mann Whitney test respectively. Differences were considered significant when the P value was less than 0.05 .

\section{Results and discussion}

\section{Characterization of the opal nanoparticles}

Figure 1 presents SEM images and XRD patterns of the O1 and O2 opals. The images illustrate spherical particles in the opals with heterogeneous size distribution that indicate an average size around 80 and $120 \mathrm{~nm}$, respectively. Size established for "secondary" particles which are considered as spherical particles smaller of the relatively large particles called agglomerates or "tertiary" structures. The secondary particles consist of smaller primary spherical particles $5-10 \mathrm{~nm}$ in diameter, which not seen in this case by the limitation of the technique [32]. The XRD patterns of all specimens show in particular a outstanding peak at $\sim 19-24^{\circ} 2 \theta$ with full-width half-maximum (FWHM) $<5.6^{\circ}$ and a peak at $\sim 36^{\circ} 2 \theta$ dominant features of the opal-C [33-35].

The FTIR spectra of all samples are illustrated in Figure 2. The typical IR spectrum of opal-C indicates an absorbance band at $620 \mathrm{~cm}^{-1}$ which is characteristic for lowcristobalite is shown in $\mathrm{O} 1$ opal (Figure $2 \mathrm{a}$ ) and $\mathrm{O} 2$ opal (Figure $2 \mathrm{~b}$ ). Furthermore, the remaining absorption bands near 1100,790 , and $480 \mathrm{~cm}^{-1}$ are common to all silicates with tetrahedrally coordinated silicon. Both samples present broad band assigned to the $\mathrm{O}-\mathrm{H}$ stretching $\left(3500 \mathrm{~cm}^{-1}, 1450 \mathrm{~cm}^{-1}\right.$ and between 1800 and $\left.2000 \mathrm{~cm}^{-1}\right)$ and band due to scissor bending vibration of molecular water $\left(1630 \mathrm{~cm}^{-1}\right)$, better defined for $\mathrm{O} 2$ opal. This sample has $\mathrm{C}-\mathrm{H}_{2}$ and $\mathrm{C}-\mathrm{H}_{3}$ absorbance group (2930 and $2980 \mathrm{~cm}^{-1}$, 

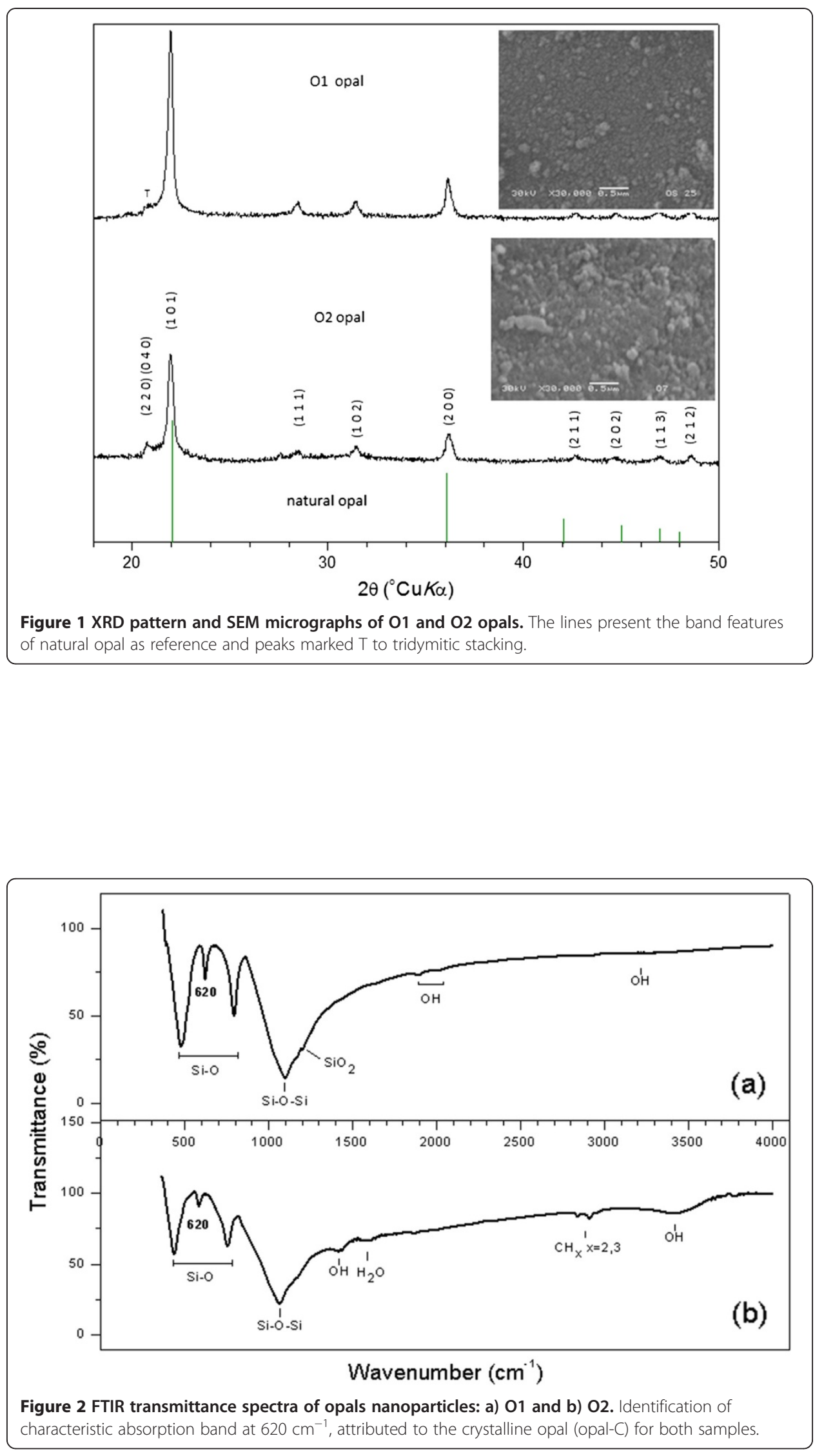
respectively) corresponding to the presence of unreacted TEOS in the silica particles, its intensity decreases with increasing ageing time. In fact, synthetic opals obtained not present quartz, revealed by the distinctive absorption band absence at $695 \mathrm{~cm}^{-1}$ $[35,36]$.

In addition to identify the type of opal used, by FTIR; the chemical analysis by EDS presents the purity of both $\mathrm{O} 1$ and $\mathrm{O} 2$ opal nanoparticles, which is shown in Figure 3 (a) and (b), respectively. The samples exhibit a composition of silicon and oxygen with major proportion in weight (wt\%); however, the presence of carbon indicates amounts of $6.79 \mathrm{wt} \%$ y $7.76 \mathrm{wt} \%$ in $\mathrm{O} 1$ and $\mathrm{O} 2$ opals, respectively. This confirms that samples contain $\mathrm{C}-\mathrm{H}$ groups or non-hydrolyzed ethoxy groups $\left(\mathrm{CH}_{3} \mathrm{CH}_{2}-\mathrm{O}\right)$. Several natural opals included in further investigations contain impurities (no-volatile) of less than $0.5 \mathrm{wt} \%$ [37]. However, FTIR and XRD show clearly that both samples are opal type C. Moreover, a study prove that the FTIR spectrum of fire opal (natural opal) indicates absorption bands related with $\mathrm{C}-\mathrm{H}$ groups [38] and other work confirms carbon presence with chemical analysis of different natural opals, but this was attributed to some organic component of the window X-ray detector [39].
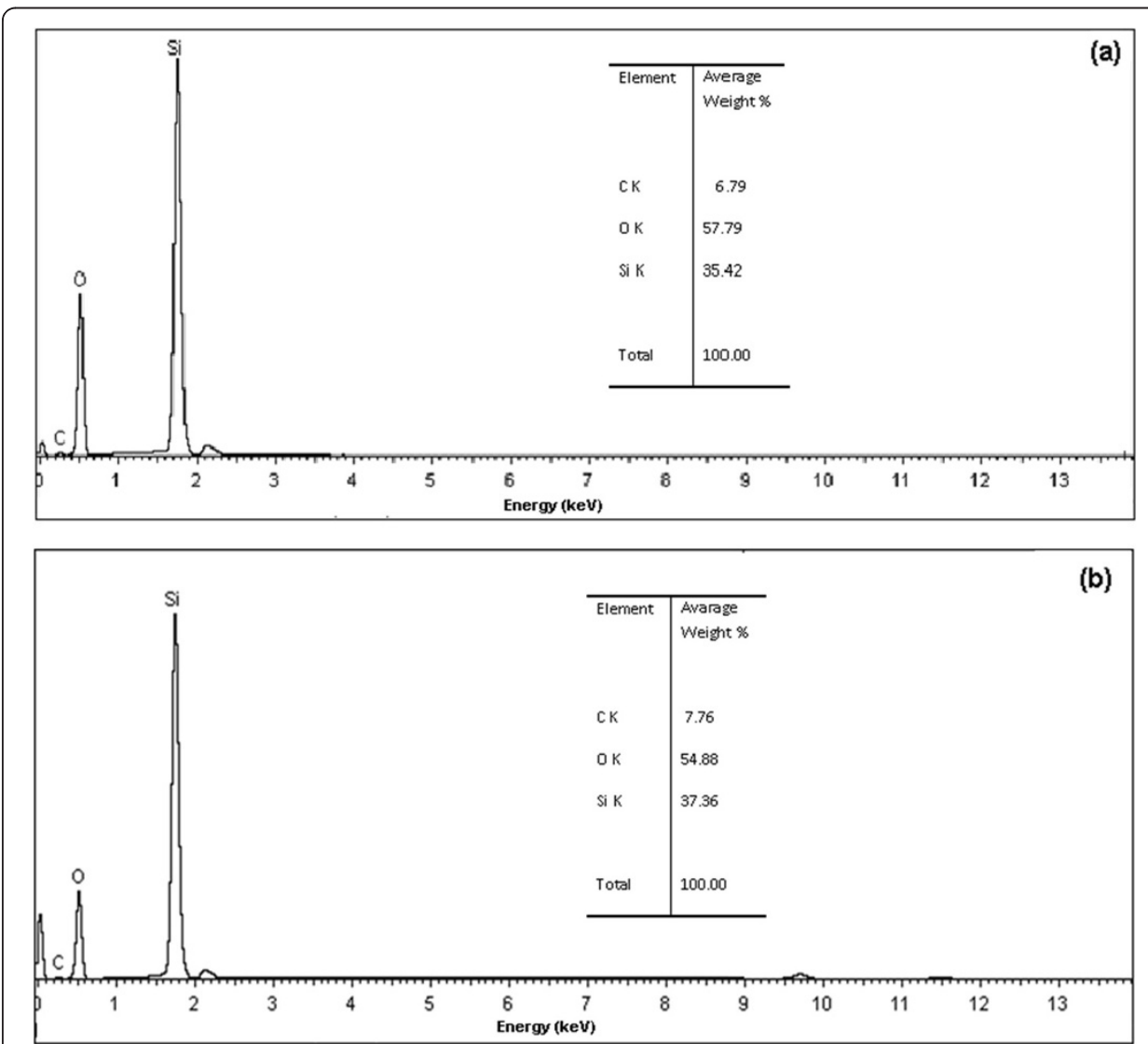

Figure 3 EDS spectrum from the nanocrystalline particles: a) 01 opal and b) 02 opal. The chemical analysis of opal nanoparticles shows a composition of silicon and oxygen, with a few concentration of carbon of unreacted TEOS. 


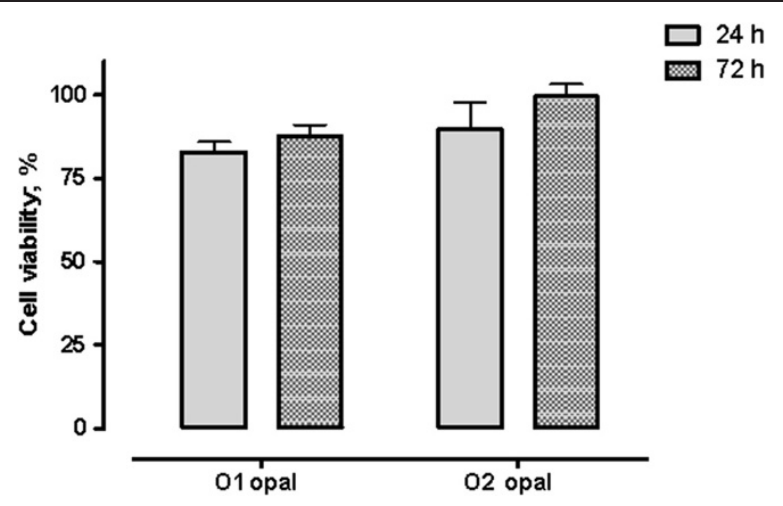

Figure 4 Effect of opal nanoparticles on MTT reduction. Significant statistically differences not were found between groups at $P>0.05$.

\section{Induction of cytotoxicity and of DNA strand breaks by opal}

Then, two different size opal particles of nanometric order were tested under identical experimental conditions to clarify the role of particle size in cytotoxicity/cell viability. Figure 4 summarizes the percent cell viability after 24 and $72 \mathrm{~h}$ exposed to opal nanoparticles. Spectrophotometric plate experiments where the concentration of opal powders was $0.25 \mu \mathrm{g} / \mathrm{mL}$ presented as a percentage of live cells incubated in O1 opal was about 80 and $85 \%$ and the cells viability in O2 opal was about 90 and $98 \%$, to each time respectively. There was an inverse relationship between particle size and MTT reduction; the opal particles less than $100 \mathrm{~nm}$ (O1 opal) induced major MTT reductions. Moreover, the test showed that the viability of the cells decreased when the exposure time of synthetic crystalline opal nanoparticles increased. The results indicate there are no significant statistically difference $(\mathrm{P}>$ 0.05) between both opals nanoparticles groups during the two evaluated periods of time, indicating less cytotoxic effect toward 3T3-cells.

On the other hand, opal nanoparticles of different sizes were tested to assess the possibility of nanosize-dependent genotoxic effect and the results are showed in Figure 5. The percentage of incorporated BrdU into the exposed 3T3 cells were translated to a

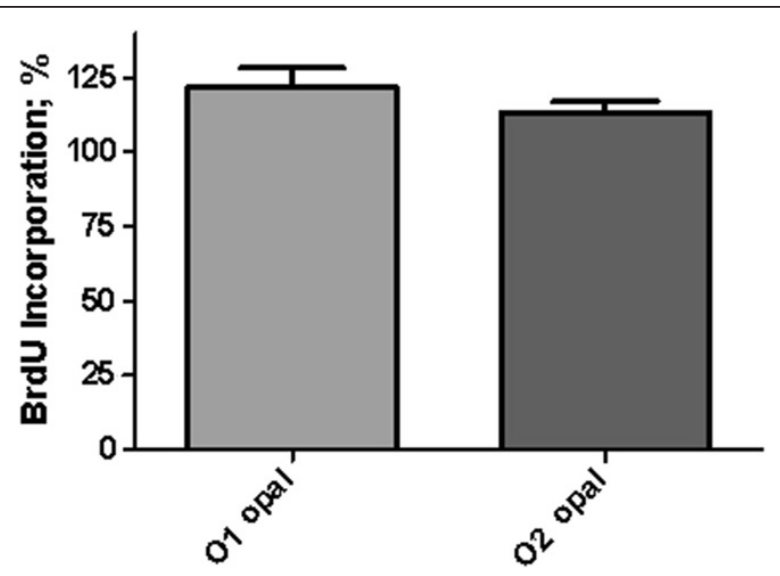

Figure 5 Histogram of BrdU incorporation in 3T3-NIH cells. The percentage of BrdU incorporation into the cells indicates that nanocrystalline opal exposure does not show significant difference between the evaluated particles $(P=0.0931)$. 
minor DNA damage of the cells. The BrdU reactive is an analog of the thymidine nucleotide which is substituted by the thymidine during the replication process (synthesis of DNA), so when the DNA is damaged, the BrdU cannot be incorporated to the DNA chain during replication process indicating a genotoxic effect. In the present study, the percentage of BrdU incorporation into the cells indicates that nanocrystalline opal exposure did not caused unrepairable DNA damage, such as strand breaks and alkali-labile sites, and its behavior is more marked for $\mathrm{O} 1 \mathrm{opal}$ corresponding at smaller size of nanoparticles, showing no significant difference between nanocrystalline particles of opals evaluated $(\mathrm{P}=0.0931)$.

It observed major grade of cytotoxicity and genotoxicity in the $\mathrm{O} 1$ opal with less particle size and low concentration of groups $\mathrm{OH}$ and $\mathrm{H}_{2} \mathrm{O}$ molecules (Figure 2). This is important regarding a detailed discussion of the surface area interaction of links $\mathrm{OH}$ of the opal with the cellular environment. Some studies support that the smaller silica nanoparticles with greater specific surface area show more toxic effects [5,40]. Indeed, there is an inverse relationship between particle size and number of surface expressed molecules, because the number of atoms or molecules on the surface of the particle may determine the material reactivity [8]. In addition, silanol $(\mathrm{SiOH})$ groups present on the surface of silica particles are capable of forming hydrogen bonds with oxygen and nitrogen groups found in biologic cell membranes, which then may lead to a loss of membrane structure, lysosomal leakage and tissue damage [11]. On the other hand, Costa et al. showed that smaller silica particles are not as extensively cross-linked, as observed from the large radius increase within liquid, due to swelling with water and ethanol; also, by its lower concentrations of ammonia, used in the synthesis, contain broadly distributed residual ethoxy groups on surfaces but also largely within the particles [41]. In fact, the oxidative state of nanomaterials at the interface is another potential design feature that can be used to mitigate cytotoxicity [22]. This case could be reason that the $\mathrm{O} 1$ opal does not present cell damage significant statistically.

Due to practically there are not studies about toxicity of crystalline opal nanoparticles, results observed of this work are compared with different crystalline and amorphous silica materials on distinct types of cells. This comparison indicates similitude in it exhibited [6,7,42-44]. Dusts composed of amorphous silica (opal), with the exception of fiberglass, are not generally considered to be harmful to humans. On the other hand, a research data suggests that there is fibrogenic activity of different forms of free silica; the action of fused silica, quartz, cristobalite and tridymite on the liver of mice [15]. More even, crystalline silica shows cytotoxicity and genotoxicity based on in vitro testing [2], apparently contradicts the work of this paper. Although, the water is considered as active agent, a study shows as the stishovite (crystalline form of silica) diluted in $\mathrm{H}_{2} \mathrm{O}$ could be even more toxic than quartz [21]. Therefore, the water attached to the surface of crystalline opal nanoparticles is an important factor in the interaction process between cells and particles, which influences to avoid toxicity. Also, the concentration of crystalline opal nanoparticles is an important parameter in biocompatibility studies. In the present study, the concentration of sample used is greater than it what might be used in practice; which indicates no damage cytotoxic or genotoxic in cells. Certainly, the physical and chemical effects observed in the interaction between surface and biological environment requires further investigation in order to provide a good physicochemical explanation for the shown phenomenon. 


\section{Conclusions}

Within the limitation of the present study we conclude that crystalline opals nanoparticles with 80 to $120 \mathrm{~nm}$ in diameter were no cytotoxic and genotoxic to the exposed mouse fibroblast cells.

\section{Competing interests}

The authors declare that they have no competing interests.

\section{Authors' contributions}

MHO, LSAT and VMC have made substantial contributions to the conception and design of the investigation. LSAT and IM were involved in the data collection. All authors read and approved the final manuscript.

\section{Acknowledgement}

The authors would like to thank for excellent technical support to: Ph. D. Marina Vega González, Miguel A. Arellano, T. Daniel Mondragón and T. Antonio Prado. M. Hernández-Ortiz is recipient of doctoral fellowship from CONACyT.

\section{Author details}

${ }^{1}$ Programa de Posgrado en Ciencia de Materiales del, Universidad de Sonora, A P 130, Hermosillo, Sonora 83000, México. ${ }^{2}$ Departamento de Investigación en Polímeros y Materiales, Universidad de Sonora, A P 130, Hermosillo, Sonora 83000, México. ${ }^{3}$ Escuela Nacional de Estudios Superiores, Universidad Nacional Autónoma de México, Unidad León, Boulevard UNAM No. 2011 Predio el Potrero y el Saucillo, C.P. 36969, León, Guanajuato, México. ${ }^{4}$ Departamento de Nanotecnología, Campus Juriquilla, Querétaro 76230, México. ${ }^{5}$ Departamento de Ingeniería Molecular de Materiales, Centro de Física Aplicada y Tecnología Avanzada, Campus Juriquilla, Querétaro 76230, México. ${ }^{6}$ Instituto de Neurobiología, Universidad Nacional Autónoma de México, Campus Juriquilla, Querétaro 76230, México. ${ }^{7}$ Departamento de Investigación en Física, Universidad de Sonora, A. P. 5-088, Hermosillo, Sonora 83190, México. ${ }^{8}$ Centro de Física Aplicada y Tecnología Avanzada, Universidad Nacional Autónoma de México, Campus Juriquilla, Querétaro 76230, México.

Received: 21 May 2012 Accepted: 1 October 2012

Published: 22 October 2012

\section{References}

1. Choi J, Zhang Q, Reip V, Wang NS, Stratmeyer ME, Hitchins VM, Goering PL: Comparison of cytotoxic and inflammatory responses of photoluminescent silicon nanoparticles with silicon micron-sized particles in RAW 264.7 macrophages. J Appl Toxicol 2009, 29:52-60.

2. Barnes CA, Elsaesser A, Arkusz J, Smok A, Palus J, Lesniak A, Salvati A, Hanrahan JP, De Jong WH, Dziubałtowska E, Stepnik M, Rydzynski K, McKerr G, Lynch I, Dawson KA, Howard CV: Reproducible comet assay of amorphous silica nanoparticles detects no genotoxicity. Nano Letters 2008, 8:3069-3074.

3. Sharma HS, Hussain S, Schlager J, Ali SF, Sharma A: Influence of nanoparticles on blood-brain barrier permeability and brain edema formation in rats. Acta Neurochirurgica Supplementum 2010, 106:359-364.

4. Savage N, Diallo MS: Nanomaterials and water purification: opportunities and challenges. J Nanopart Res 2005, 7:331-342.

5. Yu KO, Grabinski CM, Schrand AM, Murdock RC, Wang W, Gu B, Schlager JJ, Hussain SM: Toxicity of amorphous silica nanoparticles in mouse keratinocytes. J Nanopart Res 2009, 11:15-24.

6. Choi HS, Kim YJ, Song M, Song MK, Ryu JC: Genotoxicity of Nano-silica in Mammalian Cell Lines. Toxicol Environ Health Sci 2011, 3:7-13.

7. Durnev AD, Solomina AS, Daugel-Dauge NO, Zhanataev AK, Shreder ED, Nemova EP, Shreder OV, Veligura VA, Osminkina LA, Timoshenko VY, Seredenin SB: Evaluation of genotoxicity and reproductive toxicity of silicon nanocrystals. B Exp Biol Med+ 2010, 149:445-449.

8. Nel A, Xia T, Mädler L, Li N: Toxic potential of materials at the nanolevel. Science 2006, 311:622-627.

9. Nel AE, Mädler L, Velegol D, Xia T, Hoek EMV, Somasundaran P, Klaessig F, Castranova V, Thompson M: Understanding biophysicochemical interactions at the nano-bio interface. Nat Mater 2009, 8:543-557.

10. Mahmoudi M, Lynch I, Ejtehadi MR, Monopoli MP, Bombelli FB, Laurent S: Protein nanoparticle interactions: opportunities and challenges. Chem Rev 2011, 111:5610-5637.

11. Mahmoudi M, Serpooshan V: Large protein absorptions from small changes on the surface of nanoparticles. J Phys Chem C 2011, 115:18275-18283.

12. Kim YJ, Yu M, Park HO, Yang SI: Comparative study of cytotoxicity, oxidative stress and genotoxicity induced by silica nanomaterials in human neuronal cell line. Mol Cell Toxicol 2010, 6:337-344.

13. Lai JCK, Ananthakrishnan G, Jandhyam S, Dukhande W, Bhushan A, Gokhale M, Daniels CK, Leung SW: Treatment of human astrocytoma U87 cells with silicon dioxide nanoparticles lowers their survival and alters their expression of mitochondrial and cell signaling proteins. Int J Nanomedicine 2010, 5:715-723.

14. Wallace WE, Keane MJ, Murray DK, Chisholm WP, Maynard AD, Ong TM: Phospholipid lung surfactant and nanoparticle surface toxicity: Lessons from diesel soots and silicate dusts. J Nanopart Res 2006, 9:23-38.

15. Greenberg MI, Waksman J, Curtis J: Silicosis: A Review. Dis Mon 2007, 53:394-416.

16. Fanizza C, Ursini CL, Paba E, Ciervo A, Francesco AD, Maiello R, Simonea PD, Cavallo D: Cytotoxicity and DNA-damage in human lung epithelial cells exposed to respirable a-quartz. Toxicol Vitr 2007, 21:586-594.

17. Jones JB, Segnit ER: Water in sphere-type opal. Mineral Mag 1969, 37:357-361.

18. Gaillou E, Fritsch E, Aguilar-Reyes B, Rondeau B, Post J, Barreau A, Ostroumov M: Common Gem Opal: An Investigation of Micro- to Nano-Structure. Am Mineral 2008, 93:1865-1873. 
19. Masalov VM, Sukhinina NS, Emel'chenko GA: Colloidal Particles of Silicon Dioxide or the Formation of Opal-Like Structures. Physics of the Solid State 2011, 53:1135-1139.

20. Iler RK: The colloid chemistry of silica and silicates. New York: Cornell University Press; 1955.

21. Iler RK: The chemistry of silica: solubility, polymerization, colloid and surface properties, and biochemistry. New York: Wiley-Interscience; 1979.

22. Boyko V, Dovbeshko G, Fesenko O, Gorelik V, Moiseyenko V, Romanyuk V, Shvets T, Vodolazkyy P: New optical properties of synthetic opals infiltrated by DNA. Mol Cryst Liq Cryst 2011, 535:30-41.

23. Mahmoudi M, Hosseinkhani XH, Hosseinkhani M, Boutry S, Simchi A, Journeay WS, Subramani K, Laurent S: Magnetic resonance imaging tracking of stem cells in vivo using iron oxide nanoparticles as a tool for the advancement of clinical regenerative medicine. Chem Rev 2011, 111:253-280.

24. Arruebo M, Fernández-Pacheco R, Ibarra MR, Santamaría J: Magnetic Nanoparticles for Drug Delivery. Nanotoday 2007, 2:22-32.

25. Mahmoudi M, Laurent S, Shokrgozar MA, Hosseinkhan M: Toxicity Evaluations of Superparamagnetic Iron Oxide Nanoparticles: Cell "Vision" versus Physicochemical Properties of Nanoparticles. ACS Nano 2011, 5:7263-7276.

26. Mahmoudi M, Azadmanesh K, Shokrgozar MA, Journeay WS, Laurent S: Effect of Nanoparticles on the Cell Life Cycle. Chem Rev 2011, 111:3407-3432.

27. Sharifi S, Behzadi S, Laurent S, Forrest ML, Stroevee P, Mahmoudi M: Toxicity of nanomaterials. Chem Soc Rev $2012,41: 2323-2343$.

28. Laurent S, Dutz S, Häfeli UO, Mahmoudi M: Magnetic fluid hyperthermia: Focus on superparamagnetic iron oxide nanoparticles. Adv Colloid Interfac 2011, 166:8-23.

29. Mahmoudi M, Sahraian MA, Shokrgozar MA, Laurent S: Superparamagnetic iron oxide nanoparticles: promises for diagnosis and treatment of multiple sclerosis. ACS Chem Neurosci 2011, 2:118-140.

30. Stöber W, Fink A, Bohn E: Controlled growth of monodisperse silica spheres in the micron size range. J Coll Inter Sci 1968, 26:62-69.

31. Uboldi C, Bonacchi D, Lorenzi G, Hermanns M, Pohl C, Baldi G, Unger RE, Kirkpatrick CJ: Gold nanoparticles induce cytotoxicity in the alveolar type-II cell lines A549 and NCIH441. Part Fibre Toxicol 2009, 6:18-29.

32. Karpov IA, Samarov ÉN, Masalov VM, Bozhko SI, Emel'chenko GA: The Intrinsic Structure of Spherical Particles of Opal. Physics of the Solid State 2005, 47:347-351.

33. Guthrie GD, Bish DL, Reynolds RC: Modeling the X-ray diffraction pattern of opal-C. Am Mineral 1995, 80:869-872.

34. Ilieva A, Mihailova B, Tsintsov Z, Petrov O: Structural state of microcrystalline opals: a Raman spectroscopic study. Am Mineral 2007, 92:1325-1333.

35. Hernández-Ortiz M, Hernández-Padrón G, Bernal R, Cruz-Vázquez C, Vega-González M, Castaño VM: Nanostructured Synthetic Opal-C. Dig J Nanomater Bios 2012, 7:1297-1302.

36. Beganskienè A, Sirutkaitis V, Kurtinaitienè M, Juškenas R, Kareiva A: FTIR, TEM and NMR Investigations of Stöber Silica Nanoparticles. Mater Sci (Medžiagotyra) 2004, 10:287-290.

37. Graetsch H, Gies H, Topalovic I: NMR, XRD and IR study on microcrystalline opals. Phys Chem Minerals 1994 21:166-175

38. Hernández-Ortiz M, Hernández-Padrón G, Bernal R, Cruz-Vázquez C, Castaño VM: Nanocrystalline Mimetic Opals: Synthesis and Comparative Characterization. J Ceram-Silikaty 2012, in press.

39. Cortés Escobedo CA: Caracterización de Ópalos Naturales, Reproducción del Fenómeno de Opalescencia a Partir del Proceso Sol-gel y Diseño de un Sistema de Medición de Opalescencia. Mexico City, México: Unpublished Master dissertation, University Instituto Politécnico Nacional; 2005

40. Napierska D, Thomassen LCJ, Rabolli V, Lison D, Gonzalez L, Kirsch-Volders M, Martens JA, Hoet PH: Size-Dependent Cytotoxicity of Monodisperse Silica Nanoparticles in Human Endothelial Cells. Small 2009, 5:846-853.

41. Costa CAR, Valadares LF, Galembeck F: Stöber Silica Particle Size Effect on the Hardness and Brittleness of Silica Monoliths. Colloids Surf, A Physicochem Eng Asp 2007, 302:371-376.

42. Wang JJ, Sanderson BJS, Wang H: Cytotoxicity and Genotoxicity of Ultrafine Crystalline $\mathrm{SiO}_{2}$ Particulate in Cultured Human Lymphoblastoid Cells. Environ Mol Mutagen 2007, 48:151-157.

43. Laaksonen T, Santos H, Vihola H, Salonen J, Riikonen J, Heikkilä T, Peltonen L, Kumar N, Murzin DY, Lehto VP, Hirvonen J: Failure of MTT as a Toxicity Testing Agent for Mesoporous Silicon Microparticles. Chem Res Toxicol 2007, 20:1913-1918.

44. Schins RPF, Duffin R, Höhr D, Knaapen AM, Shi T, Weishaupt C, Stone V, Donaldson K, Borm PJA: Surface Modification of Quartz Inhibits Toxicity, Particle Uptake and Oxidative DNA Damage in Human Lung Epithelial Cells. Chem Res Toxicol 2002, 15:1166-1173.

doi:10.1186/1475-925X-11-78

Cite this article as: Hernández-Ortiz et al:: Biocompatibility of crystalline opal nanoparticles. BioMedical Engineering OnLine 2012 11:78. 